\title{
Triptolide induced DNA damage in A375.S2 human malignant melanoma cells is mediated via reduction of DNA repair genes
}

\author{
FU-SHIN CHUEH $^{1 *}$, YUNG-LIANG CHEN $^{2 *}$, SHU-CHUN HSU $^{3}$, JAI-SING YANG $^{4}$, \\ SHU-CHING HSUEH ${ }^{5}$, BIN-CHUAN JI ${ }^{6}$, HSU-FENG LU ${ }^{7,8}$ and JING-GUNG CHUNG ${ }^{9,10}$
}

\begin{abstract}
${ }^{1}$ Departments of Health and Nutrition Biotechnology, Asia University, Taichung 413; ${ }^{2}$ Department of Medical Laboratory Science and Biotechnology, Yuanpei University, Hsinchu 300; ${ }^{3}$ Departments of Nutrition, China Medical University, Taichung 404; ${ }^{4}$ Departments of Pharmacology, China Medical University, Taichung 404; ${ }^{5}$ Department of Clinical Pathology, Cheng Hsin General Hospital, Taipei 112; ${ }^{6}$ Division of Chest Medicine, Department of Internal Medicine, Changhua Christian Hospital, Changhua 500; ${ }^{7}$ Department of Clinical Pathology, Cheng Hsin General Hospital, Taipei 112; ${ }^{8}$ Department of Restaurant, Hotel and Institutional Management, Fu-Jen Catholic University, Taipei 510; ${ }^{9}$ Departments of Biological Science and Technology, China Medical University, Taichung 404; ${ }^{10}$ Departments of Biotechnology, Asia University, Taichung 413, Taiwan, R.O.C.
\end{abstract}

Received September 1, 2012; Accepted November 14, 2012

DOI: $10.3892 / o r .2012 .2170$

\begin{abstract}
Numerous studies have demonstrated that triptolide induces cell cycle arrest and apoptosis in human cancer cell lines. However, triptolide-induced DNA damage and inhibition of DNA repair gene expression in human skin cancer cells has not previously been reported. We sought the effects of triptolide on DNA damage and associated gene expression in A375.S2 human malignant melanoma cells in vitro. Comet assay, DAPI staining and DNA gel electrophoresis were used for examining DNA damage and results indicated that triptolide induced a longer DNA migration smear based on single cell electrophoresis and DNA condensation and damage occurred based on the examination of DAPI straining and DNA gel electrophoresis. The real-time PCR technique was used to examine DNA damage and repair gene expression (mRNA) and results indicated that triptolide led to a decrease in the ataxia telangiectasia mutated (ATM), ataxia-telangiectasia and Rad3-related (ATR), breast cancer 1, early onset (BRCA-1), p53, DNA-dependent serine/threonine protein kinase (DNA$\mathrm{PK}$ ) and $\mathrm{O}^{6}$-methylguanine-DNA methyltransferase (MGMT) mRNA expression. Thus, these observations indicated that
\end{abstract}

Correspondence to: Professor Jing-Gung Chung, Department of Biological Science and Technology, China Medical University, No. 91 Hsueh-Shih Road, Taichung 404, Taiwan, R.O.C.

E-mail: jgchung@mail.cmu.edu.tw

Dr Hsu-Feng Lu, Department of Clinical Pathology, Cheng-Hsin General Hospital, No. 45 Cheng Hsin Street, Taipei 112, Taiwan, R.O.C. E-mail: ch1835@chgh.org.tw

*Contributed equally

Key words: triptolide, DNA damage, Comet assay, DNA repair, A375.S2 cells triptolide induced DNA damage and inhibited DNA damage and repair-associated gene expression (mRNA) that may be factors for triptolide-mediated inhibition of cell growth in vitro in A375.S2 cells.

\section{Introduction}

Of the skin cancers, melanoma is the leading cause of death and the mortality rate is increasing (1-3). Thus, for all ages, melanoma is the primary focus of early detection campaigns. Sun UV has been recognized to cause skin cancer (4-6). UV can cause DNA damage of skin cells (4-6). DNA damage is involved in neurodegeneration in age-related disease, cerebral ischemia, and brain trauma including DNA damage (7-9). It was reported that in anticancer therapy, irradiation and DNA-damaging chemotherapeutic drugs play an important key role based on their ability to induce DNA double-strand breaks leading to cancer cell death (10-12). Thus, if agents can block DNA repair proteins it may lead to increase in the sensitivity of DNA damaging chemotherapeutic agents (13-16).

Triptolide (diterpenoid triepoxide; PG490) extracted from Tripterygium wilfordii Hook $F$ (TWHF) has been shown to present anti-fertility function (17), anti-neoplastic activity such as anti-leukemia (18-25), anti-human hepatocellular carcinoma cells $(25)$, colon cancer cells $(23,26,27)$ and cervical cancer cells (28). Furthermore, evidence has been shown that triptolide inhibited the growth and metastasis of various solid tumors and has been suggested capable of acting synergistically with conventional chemotherapeutic drugs $(29,30)$.

Substantial evidence has been demonstrated that triptolide induced cytotoxic effects in many human cancer cell lines but no available information exists to show triptolide-induced DNA damage in human skin cancer cells. Therefore, we investigated the effects of triptolide on DNA damage associated DNA repair 
genes expression (mRNA) in A375.S2 human malignant melanoma cells in vitro. Our findings demonstrated that triptolide induced DNA damage and also inhibited the expression of DNA repair genes in A375.S2 cells.

\section{Materials and methods}

Chemicals and reagents. Triptolide, dimethyl sulfoxide (DMSO), ethidium bromide, propidium iodide (PI), Tris- $\mathrm{HCl}$ and Triton X-100 were purchased from Sigma-Aldrich. RPMI-1640 medium, fetal bovine serum (FBS), L-glutamine, penicillin-streptomycin and trypsin-EDTA were purchased from Gibco ${ }^{\circledR} /$ Invitrogen (Grand Island, NY, USA).

Cell culture and chemical treatment. The human malignant melanoma cell line (A375.S2) was purchased from the Food Industry Research and Development Institute (Hsinchu, Taiwan). Cells were cultured with minimum essential medium (MEM) supplemented with $10 \%$ fetal bovine serum, $100 \mathrm{U} / \mathrm{ml}$ of penicillin, $100 \mu \mathrm{g} / \mathrm{ml}$ of streptomycin, and $2 \mathrm{mmol} / \mathrm{l}$ of L-glutamine in $75 \mathrm{~cm}^{2}$ tissue culture flasks and grown in a humidified $5 \%$ $\mathrm{CO}_{2}$ and $95 \%$ air at $37^{\circ} \mathrm{C}(31,32)$.

Flow cytometric assay for percentage of viable cells. Equal numbers of cells $\left(2 \times 10^{5}\right.$ cells/well) were seeded in 12-well plates and allowed to attach overnight. The cells were treated with $0.1 \%$ DMSO or triptolide $(0,15,20,25$ and $30 \mathrm{nM})$ diluted in MEM with $5 \%$ FBS for $24 \mathrm{~h}$. Cells from each treatment were stained with PI $(5 \mu \mathrm{g} / \mathrm{ml})$ and were analyzed for percentage of viable cells by using flow cytometry (Becton-Dickinson, San Jose, CA, USA) and cell viability was calculated as previously described $(33,34)$.

Comet assay and DAPI staining for DNA damage. A375.S2 cells at the density of $2 \times 10^{5}$ cells/well in 12 -well plates were incubated with triptolide at final concentrations of $0,15,20,25$ and $30 \mathrm{nM}$, vehicle ( $1 \mu \mathrm{l}$ DMSO) and $0.1 \%$ of $\mathrm{H}_{2} \mathrm{O}_{2}$ (positive control) for $24 \mathrm{~h}$ or the cells were treated with $20 \mathrm{nM}$ triptolide for $0,6,12,24$ and $48 \mathrm{~h}$ in MEM medium grown at $37^{\circ} \mathrm{C}$ in $5 \%$ $\mathrm{CO}_{2}$ and $95 \%$ air. Cells were harvested for the measurement of DNA damage using the Comet assay as described previously $(33,35,36)$. Comet tail length was calculated and quantified by using the TriTek CometScore ${ }^{\mathrm{TM}}$ software image analysis system (TriTek Corp., Sumerduck, VA, USA) as described previously $(33,35,36)$. Harvested cells were stained by DAPI then examined and photographed by using fluorescence microscopy as described elsewhere $(33,35,37)$.

DNA gel electrophoresis for DNA damage. A375.S2 cells at the density of $2 \times 10^{5}$ cells/well in 12-well plates were incubated with triptolide at final concentrations of $0,15,20,25$ and $30 \mathrm{nM}$ for $48 \mathrm{~h}$ in MEM medium grown in $5 \% \mathrm{CO}_{2}$ and $95 \%$ air at $37^{\circ} \mathrm{C}$. Cells in each well were individually isolated by using DNA isolation kit. The isolated DNA $(2 \mu \mathrm{g})$ from each treatment was examined for DNA damage by using DNA electrophoresis which was carried out in $0.5 \%$ agarose gel in Tris/ acetate buffer at $15 \mathrm{~V}$ for $2 \mathrm{~h}$. At the end of electrophoresis the DNA was stained with ethidium bromide then examined and photographed under a fluorescence microscope as previously described (38-40).
Table I. The DNA sequence was evaluated using the Primer Express software and each assay was run on an Applied Biosystems 7300 Real-time PCR system.

\begin{tabular}{ll}
\hline Primer name & \multicolumn{1}{c}{ Sequences } \\
\hline Human BRCA1 & F: CCAGGGAGTTGGTCTGAGTGA \\
& R: ACTTCCGTAAGGCATCGTAACAC \\
Human DNA-PK & F: CCAGCTCTCACGCTCTGATATG \\
& R: CAAACGCATGCCCAAAGTC \\
Human MGMT & F: CCTGGCTGAATGCCTATTTCC \\
Ruman p53 & F: GGTCTGGTGAACGACTCTTGCT \\
Human ATM & R: GGGCCTTGAAGTTAGAGAAAATTCA \\
Human ATR & R: ACTTCCGTAAGGCATCGTAACAC \\
& R: GGGAATCACGACTCGCTGAA \\
Human GAPDH & F: ACACCCACTCCTCCACCTTT \\
& R: TAGCCAAATTCGTTGTCATACC \\
\hline
\end{tabular}

Each assay was performed in triplicate to ensure reproducibility. BRCA1, breast cancer gene 1; DNA-PK, DNA-dependent serine/threonine protein kinase; MGMT, $\mathrm{O}^{6}$-methylguanine-DNA methyltransferase; ATM, ataxia telangiectasia mutated; ATR, ataxia-telangiectasia and Rad3-related; GAPDH, glyceraldehydes-3-phosphate dehydrogenase.

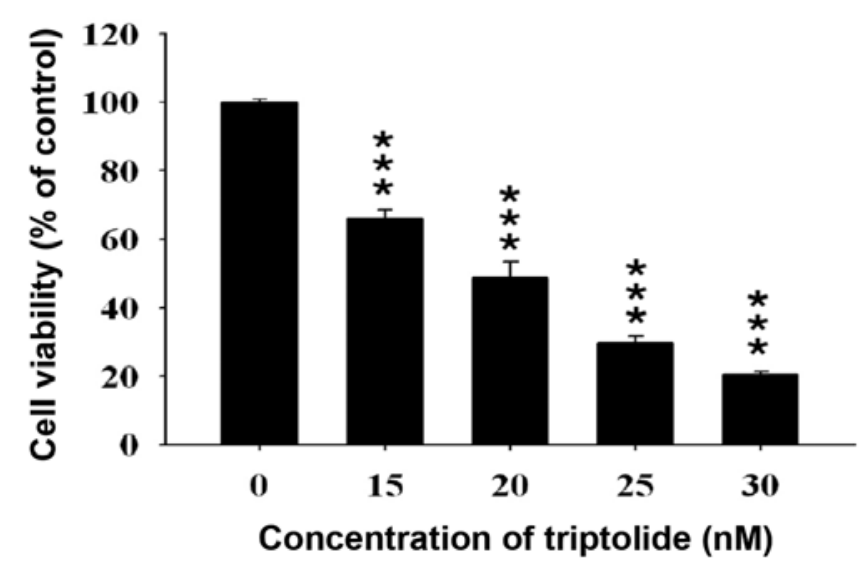

Figure 1. Triptolide decreased the viability of A375.S2 human malignant melanoma cells in vitro. A375.S2 cells $\left(5 \times 10^{5}\right.$ cells/well) were maintained in 12-well plates and were incubated with $0,10,15,25$ and $30 \mathrm{nM}$ of triptolide, vehicle ( $1 \mu 1 \mathrm{DMSO})$ as control $24 \mathrm{~h}$. Cells were harvested and stained with PI $(5 \mu \mathrm{g} / \mathrm{ml})$ and then were analyzed by flow cytometry as previously described. ${ }^{* * * *} \mathrm{P}<0.001$

Real-time PCR assay for examining the expression of DNA repair genes. A375.S2 cells at the density of $1 \times 10^{6}$ cells/well in 6 -well plates were incubated with or without $20 \mathrm{nM}$ of triptolide for $24 \mathrm{~h}$ in MEM medium grown at $37^{\circ} \mathrm{C}$ in $5 \% \mathrm{CO}_{2}$ and $95 \%$ air. The cells from each treatment were collected and total RNA was individually extracted by using the Qiagen RNeasy mini kit (Qiagen, Inc, Valencia, CA, USA) as previously described 
A

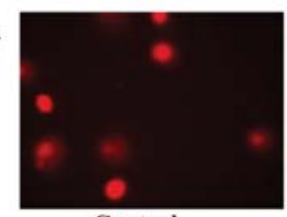

Control

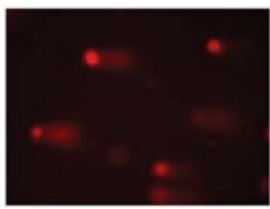

$20 \mathrm{nM}$

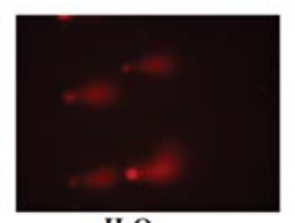

$\mathrm{H}_{2} \mathrm{O}_{2}$

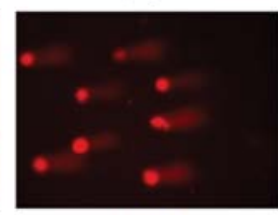

$25 \mathrm{nM}$

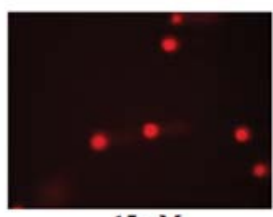

$15 \mathrm{nM}$

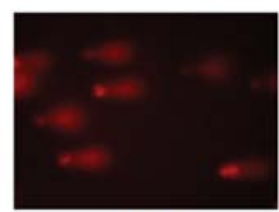

$30 \mathrm{nM}$

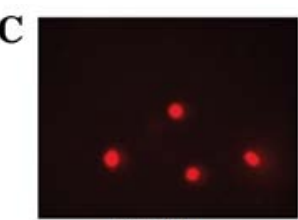

Control

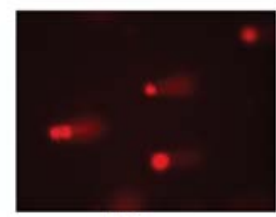

$12 \mathrm{~h}$

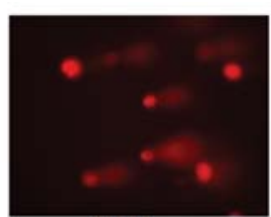

$\mathrm{H}_{2} \mathrm{O}_{2}$

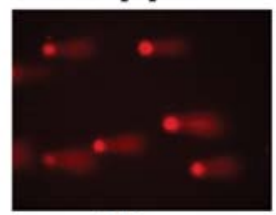

24 h

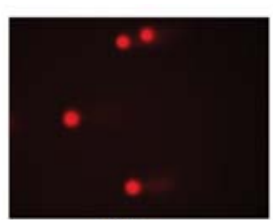

$6 \mathrm{~h}$

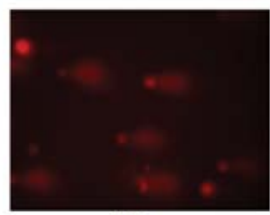

$48 \mathrm{~h}$
B

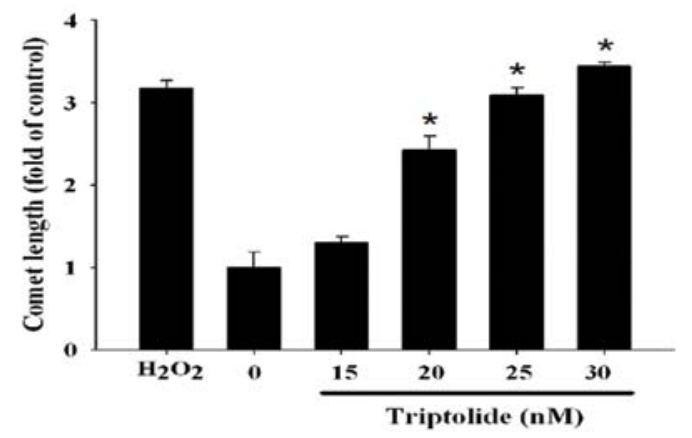

D

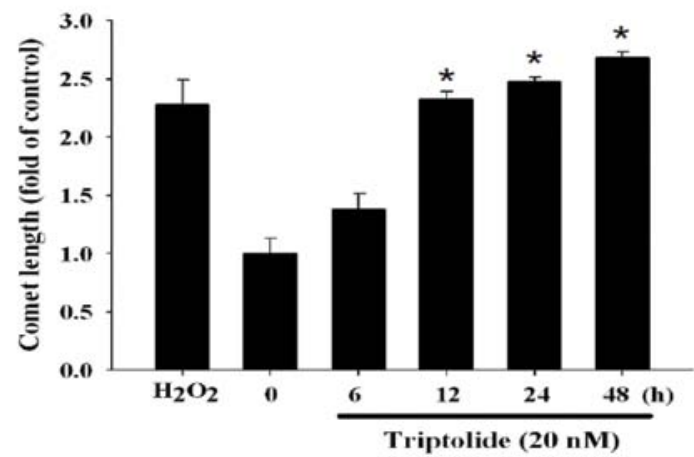

Figure 2. Differential concentration of triptolide-induced DNA damage in A375.S2 cells examined by Comet assay. The A375.S2 cells (5x105 cells/well) were maintained in 12-well plates incubated with $0,15,20,25$ and $30 \mathrm{nM}$ of triptolide, and $0.1 \%$ of $\mathrm{H}_{2} \mathrm{O}_{2}$ (positive control) for $24 \mathrm{~h}$ (A and B) or cells were incubated with $20 \mathrm{nM}$ of triptolide for $0,6,12,24$ and $48 \mathrm{~h}(\mathrm{C}$ and $\mathrm{D})$ and DNA damage was determined by Comet assay as described in Materials and methods. $\mathrm{P}<0.05$.

(41-43). Isolated RNA samples were individually reverse-transcribed for $30 \mathrm{~min}$ at $42^{\circ} \mathrm{C}$ with High Capacity cDNA Reverse Transcription kit according to the standard protocol of the supplier (Applied Biosystems, Carlsbad, CA, USA). Quantitative PCR from each sample was conducted as follows: 2 min at $50^{\circ} \mathrm{C}$, $10 \mathrm{~min}$ at $95^{\circ} \mathrm{C}$, and 40 cycles of $15 \mathrm{sec}$ at $95^{\circ} \mathrm{C}, 1 \mathrm{~min}$ at $60^{\circ} \mathrm{C}$ using $1 \mu \mathrm{l}$ of the cDNA reverse-transcribed as described above, 2X SYBR Green PCR Master Mix (Applied Biosystems) and $200 \mathrm{nM}$ of forward and reverse primers as shown in Table I, and previously described $(41,43,44)$. Each assay was run on an Applied Biosystems 7300 Real-time PCR system in triplicate. The expression fold-changes were performed by using the comparative CT method.

Statistical analysis. All studies were performed in duplicate. Results are presented as mean \pm standard deviation. One-tailed Student's t-test was used to analyze the difference between control and triptolide treated groups. Significance was defined as $\mathrm{p}<0.05$.

\section{Results}

Effect of triptolide on the percentage of viable A375.S2 cells. A375.S2 cells were incubated with 15, 20, 25 and $30 \mathrm{nM}$ of triptolide for $24 \mathrm{~h}$. At the end of incubation, all samples were collected for determining the percentage of viable cells and the results are presented in Fig. 1, which indicated that triptolide decreased the percentage of viable cells at the concentration of 15-30 nM.
Effects of triptolide on DNA in A375.S2 cells examined by Comet assay and DAPI staining. To confirm whether triptolide can induce DNA damage in A375.S2 cells, after cells were treated with triptolide DNA damage was examined by Comet assay and the results are presented in Fig. 2. Triptolide induced DNA damage in A375.S2 cells and these effects were dose-dependent (Fig. 2B) and time-dependent (Fig. 2D). The higher concentration of triptolide led to a longer DNA migration smear (Comet tail). $\mathrm{H}_{2} \mathrm{O}_{2}$ is known to be a highly reactive oxygen species, in the present studies, $0.1 \% \mathrm{H}_{2} \mathrm{O}_{2}$ induced Comet tails. Fig. 3 shows DNA damage by DAPI stain and the effects based on the mean fluorescence intensity (Fig. 3A) are dose-dependent (Fig. 3B).

Effects of triptolide on DNA in A375.S2 cells examined by DNA gel electrophoresis. To confirm whether or not triptolide can induced DNA damage in A375.S2 cells, DNA gel electrophoresis was used and results are shown in Fig. 4. The results show that triptolide induced DNA damage and fragments in A375.S2 cells (Fig. 4). The higher dose of triptolide (30 nM) led to more DNA damage and fragments than that of low dose $(15 \mathrm{nM})$ incubation in A375.S2 cells.

Effects of triptolide on DNA damage and of repair gene expression in A375.S2 cells measured by real-time PCR. Figs. 2 and 3 results show that triptolide induced DNA damage and fragments in A375.S2 cells. We investigated whether or not triptolide affects the gene expression of DNA damage and repair in A375.S2 cells. We used DNA 
A

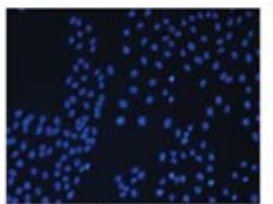

Control

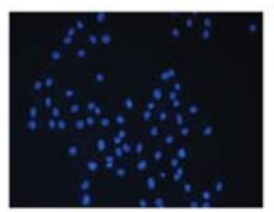

$20 \mathrm{nM}$

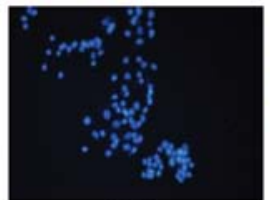

$\mathrm{H}_{2} \mathrm{O}_{2}$

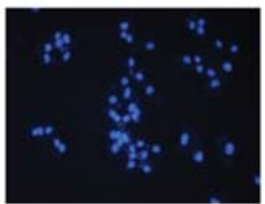

$25 \mathrm{nM}$

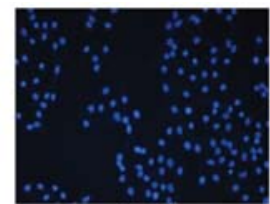

$15 \mathrm{nM}$

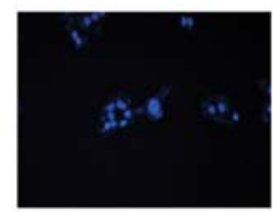

$30 \mathrm{nM}$
B

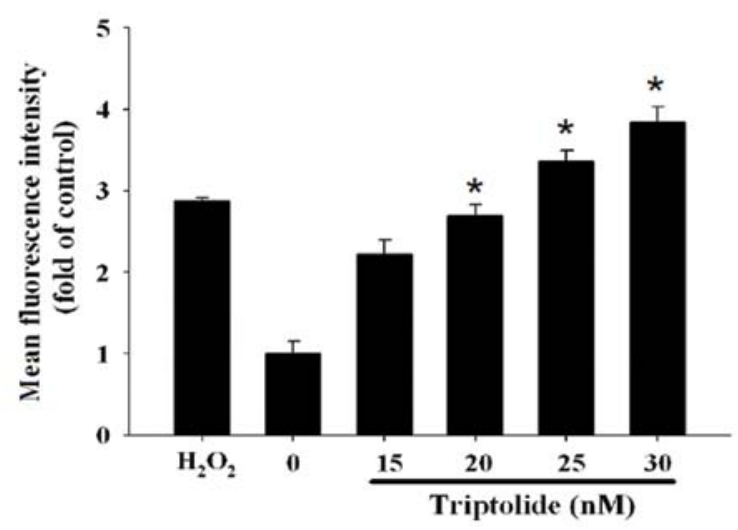

Figure 3. Triptolide-induced DNA damage in A375.S2 cells examined by DAPI staining. The A375.S2 cells $\left(5 \times 10^{5}\right.$ cells/well) were maintained in 12-well plates and incubated with $0,15,20,25$ and $30 \mathrm{nM}$ of triptolide, and $0.1 \%$ of $\mathrm{H}_{2} \mathrm{O}_{2}$ (positive control) for $24 \mathrm{~h}$ and DNA damage was determined by DAPI staining as described in Materials and methods. " $\mathrm{P}<0.05$.

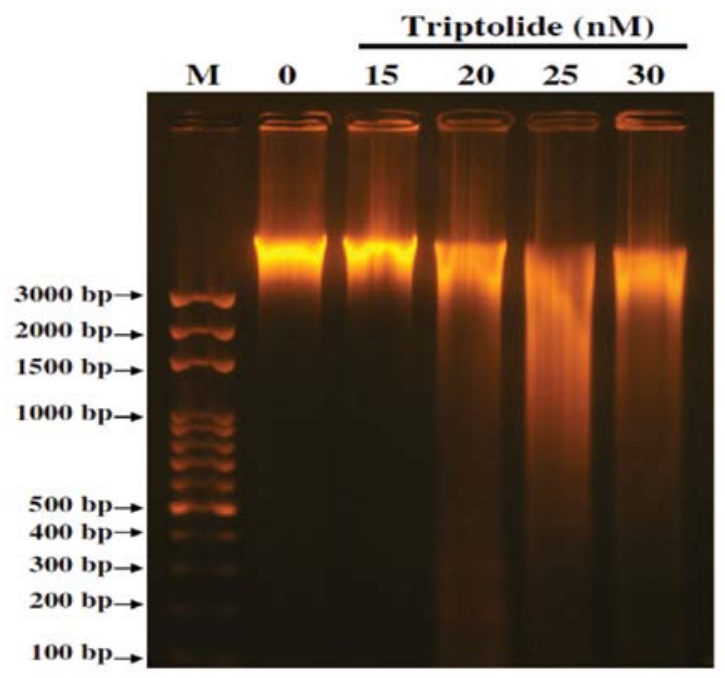

Figure 4. Triptolide-induced DNA damage in A375.S2 cells examined by DNA gel electrophoresis. The A375.S2 cells ( $1 \times 10^{6}$ cells/well) were placed in 12-well plates were incubated with $0,15,20,25$ and $30 \mathrm{nM}$ of triptolide for $48 \mathrm{~h}$. Cells were collected and DNA were isolated for DNA gel electrophoresis as described in Materials and methods.

agarose gel electrophoresis for examining the products from real-time PCR and results are shown in Fig. 5. The results indicated that all examined gene expression including ATM,

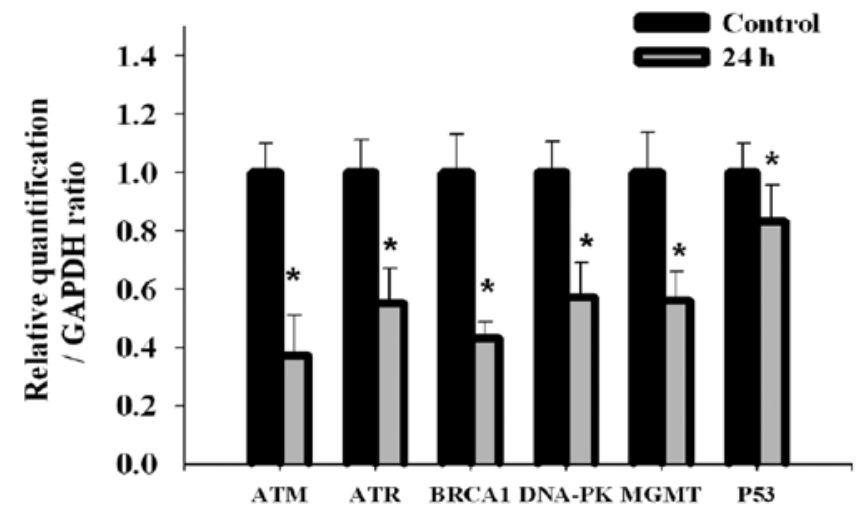

Figure 5. Triptolide-inhibited DNA damage and expression of repair genes in A375.S2 cells determined by real-time PCR. The total RNA was extracted from the A375.S2 cells after incubation with 0 and $20 \mathrm{nM}$ triptolide for $24 \mathrm{~h}$, RNA samples were reverse-transcribed, and cDNA used for real-time PCR as described in Materials and methods. The ratios of ATM, ATR, BRCA-1, p53, DNA-PK and MGMT mRNA/GAPDH are presented. Data represents mean \pm SD of three experiments. ${ }^{*} \mathrm{P}<0.05$.

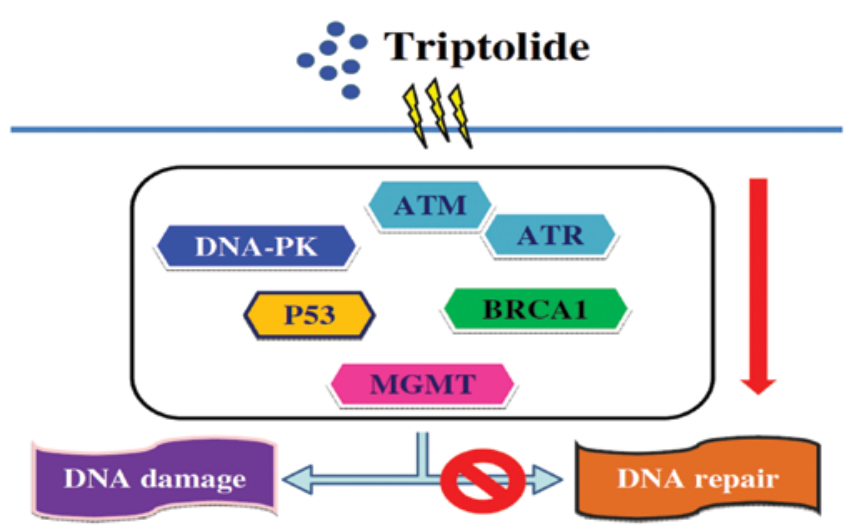

Figure 6. Proposed flow chart for triptolide-induced DNA damage and inhibition of gene expression, DNA damage and repair in A375.S2 human malignant melanoma cells.

ATR, BRCA-1, DNA-PK, MGMT and p53 mRNA were decreased in $24 \mathrm{~h}$ treatment with triptolide. ATM and BRCA-1 gene were more sensitive than the other genes (ATR, DNA-PK, MGMT and p53). P53 was the least sensitive compared to the other genes.

\section{Discussion}

Numerous experiments have shown that triptolide induces cell death via induction of apoptosis in human cancer cell lines $(26,45,46)$, but no available information exists to demonstrate triptolide induced DNA damage and affected DNA repair gene expression in human skin cancer cells. We found that A375.S2 cells treated with various concentrations of triptolide led to decreased percentage of viable cells (Fig. 1) and it also induced DNA damage (Figs. 2 and 3) and inhibited gene expression of DNA repair genes (Fig. 5) in A375.S2 cells. These findings are based on the observations from i) flow cytometric assay showing the decrease of percentage of viable cells (Fig. 1); ii) Comet assay and DAPI staining, 
the longer comet tail means higher DNA damage (Fig. 2); the light of fluorescence means higher DNA condensation (Fig. 3); iii) DNA fragments in DNA gel electrophoresis indicate high dose of triptolide treatment led to high DNA damage and fragments (Fig. 4) and iv) RT-PCR showed that triptolide inhibited the gene expression (mRNA) of DNA associated repair genes (Fig. 5).

It is well documented that Comet assay is a highly sensitive technique for DNA damage examination $(47,48)$ and trendbreak formation during the process of excision repair of DNA in cells $(49,50)$. Herein, our results showed triptolide-induced DNA damage, which was examined by Comet assay and DAPI staining. The DNA damage of A375.S2 cells from triptolide treatment was also confirmed by DNA gel electophoresis (Fig. 4).

It was reported that agent-induced DNA damage can be reduced in cells via the DNA repair system through eliminating DNA lesions $(49,50)$. Thus, we further investigated whether or not triptolide can affect the DNA repair gene expression in A 375.S2 cells and results indicated that triptolide inhibit the expression of mRNA such as ataxia telangiectasia mutated (ATM), ataxia-telangiectasia (ATR), breast cancer gene 1 (BRCA-1), p53, DNA-dependent protein kinase (DNA-PK) and $\mathrm{O}^{6}$-methylguanine DNA methyltransferase (MGMT) in the examined A375.S2 cells. The results in Fig. 5 indicate that p53 gene has the lowest sensitivity to triptolide when compared to the other examined genes.

It was reported that DNA damage responses of cells could lead to p53 activation and activated p53 regulates the cell cycle arrest, DNA repair and apoptosis $(51,52)$. The role of p53 in skin cancer cell response to triptolide-induced DNA damage and repair is unclear. Our results show that triptolide inhibited p53 gene expression in A375.S2 cells. In response to DNA damage, DNA damage checkpoints associate with cell cycle for maintaining genomic integrity (53-55). It was reported that both ATM and ATR are master checkpoint kinases which can be activated by double-stranded DNA breaks $(52,56)$. Our results also show that triptolide inhibited the ATM and ATR gene expression in A375.S2 cells.

DNA-PK plays an important role in DNA damage repair (52) and the deficiency in DNA-PK activity of human glioblastoma cells can lead to a slow, error prone repair process causing increased formation of chromosome aberrations (52). BRCA1 plays and important roles in DNA damage and repair response, homologous recombination, cell cycle regulation, protein ubiquitination and apoptosis $(57,58)$ and loss of BRCA1 causes a defective DNA repair response and $\mathrm{G}_{2} / \mathrm{M}$ cell cycle checkpoint in breast cancer cells $(57,59)$. MGMT reduces cytotoxicity of therapeutic or environmental alkylating agents $(60,61)$. Our results showed that triptolide inhibited the gene expression (mRNA) of DNA-PK, MGMT and BRCA-1.

In conclusion, A375.S2 cells were exposed to various concentrations of triptolide and DNA damage occurred. Moreover, the proposed flow chart for triptolide effect on DNA in A375.S2 human malignant melanoma cells is summarized in Fig. 6. Triptolide induces DNA damage in a dose response followed by inhibition of DNA repair-associated gene expression including ATM, ATR, BRCA-1, p53, DNA-PK and MGMT, then leading to DNA damage (Fig. 6).

\section{Acknowledgements}

This study was supported by the grant CMU-100-ASIA-4 from China Medical University.

\section{References}

1. Pang J, Assaad D, Breen D, et al: Extramammary Paget disease: review of patients seen in a non-melanoma skin cancer clinic. Curr Oncol 17: 43-45, 2010.

2. Martinez JC and Otley CC: The management of melanoma and nonmelanoma skin cancer: a review for the primary care physician. Mayo Clin Proc 76: 1253-1265, 2001.

3. Rigel DS: Epidemiology of melanoma. Semin Cutan Med Surg 29: 204-209, 2010

4. Berwick M: How do solar UV irradiance and smoking impact the diagnosis of second cancers after diagnosis of melanoma?: No answer yet. Dermatoendocrinology 4: 18-19, 2012.

5. Pfeifer GP and Besaratinia A: UV wavelength-dependent DNA damage and human non-melanoma and melanoma skin cancer. Photochem Photobiol Sci 11: 90-97, 2012.

6. Aceituno-Madera P, Buendia-Eisman A, Olmo FJ, JimenezMoleon JJ and Serrano-Ortega S: Melanoma, altitude, and UV-B radiation. Actas Dermosifiliogr 102: 199-205, 2011 (In Spanish).

7. Mathew A, Lindsley TA, Sheridan A, et al: Degraded mitochondrial DNA is a newly identified subtype of the damage associated molecular pattern (DAMP) family and possible trigger of neurodegeneration. J Alzheimers Dis 30: 617-627, 2012.

8. Baltanas FC, Casafont I, Weruaga E, Alonso JR, Berciano MT and Lafarga M: Nucleolar disruption and cajal body disassembly are nuclear hallmarks of DNA damage-induced neurodegeneration in purkinje cells. Brain Pathol 21: 374-388, 2011.

9. Barzilai A: DNA damage, neuronal and glial cell death and neurodegeneration. Apoptosis 15: 1371-1381, 2010.

10. Engelmann D and Putzer BM: Translating DNA damage into cancer cell death-A roadmap for E2F1 apoptotic signalling and opportunities for new drug combinations to overcome chemoresistance. Drug Resist Updat 13: 119-131, 2010.

11. Ye Y, Xiao Y, Wang W, et al: Inhibition of expression of the chromatin remodeling gene, SNF2L, selectively leads to DNA damage, growth inhibition, and cancer cell death. Mol Cancer Res 7: 1984-1999, 2009.

12. Suganuma M, Kawabe T, Hori H, Funabiki T and Okamoto T: Sensitization of cancer cells to DNA damage-induced cell death by specific cell cycle G2 checkpoint abrogation. Cancer Res 59: 5887-5891, 1999.

13. Potter AJ and Rabinovitch PS: The cell cycle phases of DNA damage and repair initiated by topoisomerase II-targeting chemotherapeutic drugs. Mutat Res 572: 27-44, 2005.

14. Friedmann B, Caplin M, Hartley JA and Hochhauser D: Modulation of DNA repair in vitro after treatment with chemotherapeutic agents by the epidermal growth factor receptor inhibitor gefitinib (ZD1839). Clin Cancer Res 10: 6476-6486, 2004.

15. Kerklaan PR, Bouter S, van Elburg PE and Mohn GR: Evaluation of the DNA repair host-mediated assay. II. Presence of genotoxic factors in various organs of mice treated with chemotherapeutic agents. Mutat Res 164: 19-29, 1986.

16. Norin AJ and Goldschmidt EP: Effect of mutagens, chemotherapeutic agents and defects in DNA repair genes on recombination in $\mathrm{F}^{\prime}$ partial diploid Escherichia coli. Mutat Res 59: 15-26, 1979.

17. Hikim AP, Lue YH, Wang C, Reutrakul V, Sangsuwan R and Swerdloff RS: Posttesticular antifertility action of triptolide in the male rat: Evidence for severe impairment of cauda epididymal sperm ultrastructure. J Androl 21: 431-437, 2000.

18. Zhou GS, Hu Z, Fang HT, et al: Biologic activity of triptolide in $\mathrm{t}(8 ; 21)$ acute myeloid leukemia cells. Leuk Res 35: 214-218, 2011.

19. Mak DH, Schober WD, Chen W, et al: Triptolide induces cell death independent of cellular responses to imatinib in blast crisis chronic myelogenous leukemia cells including quiescent CD34 ${ }^{+}$ primitive progenitor cells. Mol Cancer Ther 8: 2509-2516, 2009.

20. Shi X, Jin Y, Cheng C, et al: Triptolide inhibits Bcr-Abl transcription and induces apoptosis in STI571-resistant chronic myelogenous leukemia cells harboring T315I mutation. Clin Cancer Res 15: 1686-1697, 2009.

21. Pigneux A, Mahon FX, Uhalde M, et al: Triptolide cooperates with chemotherapy to induce apoptosis in acute myeloid leukemia cells. Exp Hematol 36: 1648-1659, 2008. 
22. Yao GH, Luan JF, Ye D, et al: Effects of triptolide on proliferation and apoptosis of Jurkat cell line in acute T lymphocytic leukemia. Zhongguo Shi Yan Xue Ye Xue Za Zhi 16: 506-509, 2008 (In Chinese).

23. Tong X, Zheng S, Jin J, Zhu L, Lou Y and Yao H: Triptolide inhibits cyclooxygenase- 2 and inducible nitric oxide synthase expression in human colon cancer and leukemia cells. Acta Biochim Biophys Sin 39: 89-95, 2007.

24. Lou YJ and Jin J: Triptolide down-regulates bcr-abl expression and induces apoptosis in chronic myelogenous leukemia cells. Leuk Lymphoma 45: 373-376, 2004.

25. Chan EW, Cheng SC, Sin FW and Xie Y: Triptolide induced cytotoxic effects on human promyelocytic leukemia, T cell lymphoma and human hepatocellular carcinoma cell lines. Toxicol Lett 122: 81-87, 2001.

26. Liu J, Shen M, Yue Z, et al: Triptolide inhibits colon-rectal cancer cells proliferation by induction of G1 phase arrest through upregulation of p21. Phytomedicine 19: 756-762, 2012.

27. Liu Y, Song F, Wu WK, et al: Triptolide inhibits colon cancer cell proliferation and induces cleavage and translocation of 14-3-3 epsilon. Cell Biochem Funct 30: 271-278, 2012.

28. Kim MJ, Lee TH, Kim SH, Choi YJ, Heo J and Kim YH: Triptolide inactivates Akt and induces caspase-dependent death in cervical cancer cells via the mitochondrial pathway. Int J Oncol 37: 1177-1185, 2010.

29. Zhang C, Cui GH, Liu F, Wu QL and Chen Y: Inhibitory effect of triptolide on lymph node metastasis in patients with nonHodgkin lymphoma by regulating SDF-1/CXCR4 axis in vitro. Acta Pharmacol Sin 27: 1438-1446, 2006.

30. Yang S, Chen J, Guo Z, et al: Triptolide inhibits the growth and metastasis of solid tumors. Mol Cancer Ther 2: 65-72, 2003.

31. Hsiao YP, Yu CS, Yu CC, et al: Triggering apoptotic death of human malignant melanoma a375.S2 cells by bufalin: involvement of caspase cascade-dependent and independent mitochondrial signaling pathways. Evid Based Complement Alternat Med 2012: 591241, 2012

32. Lo C, Lai TY, Yang JS, et al: Gallic acid inhibits the migration and invasion of A375.S2 human melanoma cells through the inhibition of matrix metalloproteinase-2 and Ras. Melanoma Res 21: $267-273,2011$.

33. Yu CS, Huang AC, Yang JS, et al: Safrole induces G0/G1 phase arrest via inhibition of cyclin $\mathrm{E}$ and provokes apoptosis through endoplasmic reticulum stress and mitochondrion-dependent pathways in human leukemia HL-60 cells. Anticancer Res 32 $1671-1679,2012$.

34. Liu KC, Ho HC, Huang AC, et al: Gallic acid provokes DNA damage and suppresses DNA repair gene expression in human prostate cancer PC-3 cells. Environ Toxicol: Sept. 2, 2011 (Epub ahead of print)

35. Ni CH, Yu CS, Lu HF, et al: Chrysophanol-induced cell death (necrosis) in human lung cancer A549 cells is mediated through increasing reactive oxygen species and decreasing the level of mitochondrial membrane potential. Environ Toxicol: Jul. 30 , 2012 (Epub ahead of print).

36. Yu CC, Ko FY, Yu CS, et al: Norcantharidin triggers cell death and DNA damage through S-phase arrest and ROS-modulated apoptotic pathways in TSGH 8301 human urinary bladder carcinoma cells. Int J Oncol 41: 1050-1060, 2012.

37. Ni CH, Chen PY, Lu HF, et al: Chrysophanol-induced necroticlike cell death through an impaired mitochondrial ATP synthesis in Hep3B human liver cancer cells. Arch Pharm Res 35: 887-895, 2012.

38. Tsai SC, Yang JS, Peng SF, et al: Bufalin increases sensitivity to AKT/mTOR-induced autophagic cell death in SK-HEP-1 human hepatocellular carcinoma cells. Int J Oncol 41: 1431-1442, 2012.

39. Chen HY, Lu HF, Yang JS, et al: The novel quinolone CHM-1 induces DNA damage and inhibits DNA repair gene expressions in a human osterogenic sarcoma cell line. Anticancer Res 30 4187-4192, 2010

40. Lin YT, Yang JS, Lin SY, et al: Diallyl disulfide (DADS) induces apoptosis in human cervical cancer Ca Ski cells via reactive oxygen species and $\mathrm{Ca}^{2+}$-dependent mitochondria-dependent pathway. Anticancer Res 28: 2791-2799, 2008.

41. Chen YY, Chiang SY, Lin JG, et al: Emodin, aloe-emodin and rhein induced DNA damage and inhibited DNA repair gene expression in SCC-4 human tongue cancer cells. Anticancer Res 30: 945-951, 2010.
42. Ho YT, Lu CC, Yang JS, et al: Berberine induced apoptosis via promoting the expression of caspase- $8,-9$ and -3 , apoptosisinducing factor and endonuclease G in SCC-4 human tongue squamous carcinoma cancer cells. Anticancer Res 29: 4063-4070, 2009.

43. Lu HF, Yang JS, Lai KC, et al: Curcumin-induced DNA damage and inhibited DNA repair genes expressions in mouse-rat hybrid retina ganglion cells (N18). Neurochem Res 34: 14911497, 2009.

44. Ji BC, Yu CC, Yang ST, et al: Induction of DNA damage by deguelin is mediated through reducing DNA repair genes in human non-small cell lung cancer NCI-H460 cells. Oncol Rep 27: 959-964, 2012.

45. Wu PP, Liu KC, Huang WW, et al: Triptolide induces apoptosis in human adrenal cancer NCI-H295 cells through a mitochondrialdependent pathway. Oncol Rep 25: 551-557, 2011.

46. Huang W, He T, Chai C, et al: Triptolide inhibits the proliferation of prostate cancer cells and down-regulates SUMO-specific protease 1 expression. PLoS One 7: e37693, 2012.

47. Petriccione $M$ and Ciniglia C: Comet assay to assess the genotoxicity of Persian walnut (Juglans regia L.) husks with statistical evaluation. Bull Environ Contam Toxicol 89: 166-171, 2012.

48. Kwasniewska J, Grabowska M, Kwasniewski M and Kolano B: Comet-FISH with rDNA probes for the analysis of mutageninduced DNA damage in plant cells. Environ Mol Mutagen 53: 369-375, 2012

49. Goutham HV, Mumbrekar KD, Vadhiraja BM, et al: DNA double-strand break analysis by $\gamma-\mathrm{H} 2 \mathrm{AX}$ foci: A useful method for determining the overreactors to radiation-induced acute reactions among head-and-neck cancer patients. Int J Radiat Oncol Biol Phys: Jul. 24, 2012 (Epub ahead of print).

50. Savina NV, Smal MP, Kuzhir TD, Ershova-Pavlova AA and Goncharova RI: DNA-damage response associated with occupational exposure, age and chronic inflammation in workers in the automotive industry. Mutat Res 748: 21-28, 2012

51. Pennington KP, Walsh T, Lee M, et al: BRCA1,TP53, and CHEK2 germline mutations in uterine serous carcinoma. Cancer: Jul. 18, 2012 (Epub ahead of print).

52. Serrano MA, Li Z, Dangeti M, et al: DNA-PK, ATM and ATR collaboratively regulate p53-RPA interaction to facilitate homologous recombination DNA repair. Oncogene: Jul. 16, 2012 (Epub ahead of print).

53. Fortini P, Ferretti C, Pascucci B, et al: DNA damage response by single-strand breaks in terminally differentiated muscle cells and the control of muscle integrity. Cell Death Differ: Jun. 15, 2012 (Epub ahead of print).

54. Jia YG, Yang YM, Zuo B, Guo LD and Lou JY: DNA damage response in ovarian clear cell adenocarcinoma. Sichuan Da Xue Xue Bao Yi Xue Ban 43: 331-334, 2012 (In Chinese).

55. Wong VC, Cash HL, Morse JL, Lu S and Zhitkovich A: S-phase sensing of DNA-protein crosslinks triggers TopBP1-independent ATR activation and p53-mediated cell death by formaldehyde. Cell Cycle 11: 2526-2537, 2012.

56. Boltz KA, Leehy K, Song X, Nelson AD and Shippen DE: ATR cooperates with CTC1 and STN1 to maintain telomeres and genome integrity in Arabidopsis. Mol Biol Cell 23: 1558-1568, 2012.

57. Tammaro C, Raponi M, Wilson DI and Baralle D: BRCA1 exon 11 alternative splicing, multiple functions and the association with cancer. Biochem Soc Trans 40: 768-772, 2012.

58. Pessetto ZY, Yan Y, Bessho T and Natarajan A: Inhibition of BRCT(BRCA1)-phosphoprotein interaction enhances the cytotoxic effect of olaparib in breast cancer cells: a proof of concept study for synthetic lethal therapeutic option. Breast Cancer Res Treat 134: 511-517, 2012

59. Yarden RI, Metsuyanim S, Pickholtz I, Shabbeer S, Tellio H and Papa MZ: BRCA1-dependent Chk1 phosphorylation triggers partial chromatin disassociation of phosphorylated Chk1 and facilitates S-phase cell cycle arrest. Int J Biochem Cell Biol 44: 1761-1769, 2012.

60. Silber JR, Bobola MS, Blank A and Chamberlain MC: O(6)Methylguanine-DNA methyltransferase in glioma therapy: Promise and problems. Biochim Biophys Acta 1826: 71-82, 2012.

61. Fumagalli C, Pruneri G, Possanzini P, et al: Methylation of O6-methylguanine-DNA methyltransferase (MGMT) promoter gene in triple-negative breast cancer patients. Breast Cancer Res Treat 134: 131-137, 2012. 